\title{
Pre-service physical education teachers' technological pedagogical content knowledge, technology integration self-efficacy and instructional technology outcome expectations
}

\author{
Kivanc Semiz and Mustafa Levent Ince \\ Middle East Technical University
}

\begin{abstract}
The purposes of this study were to (1) identify the Technological Pedagogical Content Knowledge (TPACK), Technology Integration Self Efficacy (TISE) and Instructional Technology Outcome Expectations (ITOE) of pre-service physical education teachers, (2) examine the relationships among TPACK, TISE and ITOE, and lastly (3) examine the differences between pre-service physical education teachers who perceived and who did not perceive technology integration by their university instructors on TPACK, TISE, and ITOE scores. Findings indicate that while TPACK, TISE and ITOE perceptions of pre-service physical education teachers were at satisfactory levels, university instructors were not good role models in the use of technology in their classrooms. Pre-service teachers reported that integration of physical education and sport-related emerging technologies were almost non-existent in the teaching practices within the university setting. TPACK, TISE, and ITOE were moderately related with each other $(p<0.05)$. Pre-service teachers' self-perceptions of TPACK, TISE, and ITOE were positively influenced by their perception of university instructors' technology integration into teaching in university courses $(p<0.05)$. Providing professional development programs for the teacher education program instructors, both in technology integration in teaching and in emerging physical education and sportsrelated technologies, is recommended.
\end{abstract}

\section{Introduction}

In recent years, the rapid advancement of technology has created new interests and tools for use in the educational domain. Researchers have identified different instructional, sport and physical education-related technologies that can potentially enhance the effectiveness of teaching physical education (Roblyer \& Doering, 2005). In particular, the development of wireless technology, computer projection systems, physical activity monitoring systems, and active gaming devices (using video games for physical activity) and software provide new opportunities in the gym (NASPE, 2009). Technological devices commonly used in physical education include computers and laptops, LCD projectors, digital video and digital cameras, audio equipment, heart rate monitors, pedometers, handheld devices including mobile phones, PDAs, GPS, and video game consoles including "exergame" dance mats (Mohnsen 2008). In addition to technological devices, educational sport software and the Internet are also used to support physical education courses.

Kretschmann (2010) described three kinds of sports-related software to use in teaching sports and physical education: 1) videos of the specific sport techniques and game 
tactics; 2) software for analysing game play (e.g., Simi Scout) or human movement (e.g., Simi Motion); and 3) commercial gaming software that can have a motivating effect in educational affairs. Moreover, while the Internet provides easy access to knowledge about everything including scientific and non-scientific information, it also provides different platforms for easy and cheap communication with others (e.g., email, video conferencing, group discussion opportunities). Macdonald and Hay (2010) identified the use of the above-mentioned technologies in physical education in the context of four main purposes: 1) to facilitate the integration of movement principles with movement performances; 2 ) to generate information for the application and evaluation of movement principles; 3) to develop formative assessment processes; and 4) to acquire summative assessment evidence for movement performances.

As previously cited examples illustrate, technology is becoming an inseparable part of physical education with each passing day. Therefore, teachers' technological knowhow has become crucial for the successful integration of technology in education (So \& Kim, 2009). However, studies have suggested that many teachers remain unclear about how to use technology to assist their teaching. While teachers sometimes use the Internet to attract students' attention, they do not know how to use it to facilitate students' development (Lee \& Tsai, 2008). In the teaching process, it is important not only how you teach (pedagogy) and what you teach (content) but also which materials (technology) you use while teaching (Jones \& Moreland, 2004). Mishra and Koehlers' (2006) technological pedagogical content knowledge (TPACK) construct explains the technological skills that teachers should have for more effective teaching. Teachers' level of TPACK is argued as the determining factor moderating teachers' abilities to successfully integrate technology into education (So \& Kim, 2009; Koh, Chai \& Tsai, 2010; Tee \& Lee, 2011).

Additionally, teachers' confidence (self-efficacy) and motivation (outcome expectations) with regards to integrating technology in education are considered important variables in teaching effectiveness (Niederhauser \& Perkmen, 2010). The technology integration self-efficacy (TISE) and instructional technology outcome expectations (ITOE) constructs have mutual relationships in the prediction of technology integration performance (Perkmen, 2008). Studies have also indicated that participants with high self-efficacy also have high outcome expectations (Wojcicki, White, \& McAuley, 2009). Therefore, a study that examines the combination of these three constructs, TPACK, TISE, and ITOE, with pre-service physical education teachers may provide valuable information to the literature on the effective incorporation of technology in education.

\section{Technological pedagogical content knowledge}

The construct of TPACK was conceived based on Shulman's (1987) Pedagogical Content Knowledge (PCK) (Mishra \& Koehler, 2006). Schulman proposed in his model that there is a certain domain of knowledge including an understanding of both pedagogy (teaching methods, student needs and readiness, etc.) and the context in which it is taught. In 2006, Mishra and Koehler defined technological knowledge (TK) as a teacher's set of skills that must be learned for meaningful teaching. Consequently, the relationship between technological knowledge and pedagogical content knowledge forms the basis of Technological Pedagogical Content Knowledge (TPACK; also 'TPCK' in some writings). Further definitions and descriptions of relevant terminology follow. 
First, technological knowledge (TK) is knowledge about analogue technologies, such as books, pens, blackboards, etc., and digital technologies, such as computers, the Internet and digital video. This includes the skills that require the use of particular technologies in teaching activities (Mishra \& Koehler, 2006). In the physical education field, for example, computer-based teacher observation systems can be used to rate specific skills or provide video analysis while giving feedback to students.

Second, content knowledge (CK) refers to the mastering of major facts, concepts and relationships within a particular field. Most importantly, this knowledge is independent of any pedagogical activities or how one might use methods or strategies to teach (Cox, 2008). For example, a physical education teacher should possess a basic understanding of motor learning and control, anatomy, exercise physiology, sport and exercise psychology, etc. According to the Turkish Physical Education Curriculum (2007), a physical education teacher should be proficient in the areas of movement, knowledge and skills and active participation and healthy lifestyles.

Next, pedagogical knowledge (PK) refers to techniques or methods of teaching and strategies for evaluating student understanding (Mishra \& Koehler, 2006). For example, when teaching a skill or a movement in physical education, a teacher should consider child development and student needs as well as behaviours and motivation. All of these aspects require a sufficient PK.

Pedagogical content knowledge (PCK), proposed by Shulman (1987), is the combination of the knowledge of teaching strategies and concepts to be taught. For instance, a basketball lesson cannot be taught in the same manner with third-grade students as with sixth graders. Developmentally appropriate instructional strategies should be determined according to students' age and grade levels.

It follows then that technological pedagogical knowledge (TPK) refers to one's knowledge of the various technologies, which can be integrated and used in educational settings. For example, a physical education teacher, who has high TPK, can easily select the appropriate tool or device to use in teaching by taking into consideration a child's age or readiness level.

Technological content knowledge (TCK) refers to one's awareness of the available technology, knowing how to use it, and understanding its purpose within the content of the specific subject matter. In physical education, choosing and using a proper technology for teaching a specific sport or a skill can be crucial. Therefore, adequate teacher competency requires high TCK.

An example of a good TPACK in physical education would be the use of video cameras to record certain dance moves and provide feedback to students while using question and answer methods. What follows next is a discussion of available TPACK studies.

\section{TPACK studies}

After being proposed by Mishra and Koehler (2006), TPACK has increasingly captured the interest of researchers and educators. However, even the originators of TPACK acknowledge the difficulties faced when integrating technology with education. For example, the rapid rate of technological change can make existing modalities quickly 
outdated. Additionally, inappropriate software design may cause some difficulties for integration with education, because most technologies are designed for the world of business and work, not education. And lastly, TPACK originators claim that merely introducing technology to the educational process is insufficient because teachers need to understand the appropriate technology to incorporate it in their teaching. Recent studies examining pre-service and in-service teachers' levels of TPACK are summarised below.

Koh, Chai and Tsai (2010) recently examined the profile of Singaporean pre-service teachers in terms of their TPACK levels. According to their findings, pre-service teachers rated themselves as slightly above average in each factor of TPACK. They also failed to find an effect of pre-service teachers' age and teaching level on TPACK variables. In another study, Lee \& Tsai (2008) found that older and more experienced teachers reported low levels of self-efficacy with respect to TPACK, while teachers with more experience using the Internet had higher levels of self-efficacy with respect to TPACK than those with less experience. Pre-service teachers' perceptions of TPACK and their cognitive difficulties in applying TPACK were examined by So \& Kim (2009). In their study, they found that after teachers enrolled in a 12-week module on information and communication technologies (ICT) integration for teaching and learning, teachers had difficulty finding appropriate ICT tools and resources relevant to their targeted students and to related design tasks and learning activities.

In another study, teachers improved their TPACK competencies after participation in an instructional technology course for developing first and second-year pre-service primary education teachers (Angeli \& Valanides, 2009). Similarly, Agyei and Voogt (2012) and Gao et al. (2011) indicated that interventions designed to develop technology integration by pre-service teachers were effective, and as a result of interventions, pre-service teachers began to consider technology as a tool for developing student learning, instead of simply viewing technology as a tool for reinforcement or demonstration.

In summary, the above-mentioned six studies indicated that the TPACK levels of preservice teachers were slightly above average (Koh, Chai \& Tsai, 2010), pre-service teachers had certain weaknesses in technology integration (So \& Kim, 2009), and younger teachers and teachers with more experience with technology had better TPACK scores (Lee \& Tsai, 2008). If the learning environment for technology integration competency is well established, both pre-service and in-service teachers can improve their TPACK scores (Angeli \& Valanides, 2009; Agyei \& Voogt, 2012, Gao et al., 2011).

To the authors' knowledge, no study has directly examined the use of technology characteristics of the pre-service and in-service physical education teachers within the TPACK framework. Most studies of technology integration within the physical education literature have focused on competency in technological device use, and integration of certain technologies in teaching with pre-service and in-service physical education teachers (Russell, 2007; Woods et al., 2008; Strand \& Bender, 2011). There have also been limited numbers of studies dealing with the effects of technology interventions on pre-service and in-service physical education teachers' related characteristics (Ince, Goodway, Ward \& Lee, 2006; Cote, Chen, \& Keppell, 2008; McCaughtry et al., 2008; Mohamed \& El Rheem, 2010). 
In the Turkish physical education setting, specifically, a few studies exist on the use of technology by teachers (Yaman, 2008; Mavi, 2007; Yaman, 2007; Yilmaz, 2008; Yilmaz, et al., 2010). According to these studies, women and younger physical education teachers use educational technologies more than men and older physical education teachers, respectively (Yaman, 2008). Physical education teachers' levels of Internet usage were low, and they used the Internet mostly for social communications (Mavi, 2007). Teachers who had personal computers at home were more competent in using office and multimedia programs, compared to teachers who did not (Yaman, 2007). Moreover, university physical education department instructors' attitudes towards using technology in teaching were positive (Yilmaz, 2008), and a physical education teacher education program on students' use of technological materials in education positively affected their attitudes towards the use of technology in teaching (Yilmaz, Ulucan \& Pehlivan, 2010).

\section{Technology integration self-efficacy and outcome expectations}

Based on social cognitive theory (Bandura, 1986), which defines human functioning via personal, behavioural, and environmental factors, Social Cognitive Career Theory (SCCT) explains academic and career-related behaviours (Lent, Brown \& Hackett, 2002). Selfefficacy and outcome expectations are two of the main cognitive factors of SCCT. Selfefficacy is observed as a major determinant of human action and is defined as the perception of one's own capability to carry out a desired action (Bandura, 1997). Outcome expectation is defined as the judgment of the likely consequence of a given action (Bandura, 1986). If one believes that an action can produce the desired result, then that belief can be an important motivation, which is called an outcome expectation.

To understand the decision-making process in technology utilisation, researchers have examined the relationships between self-efficacy and outcome expectation. For example, positive relationships have been found between self-efficacy and computer skills performance (Compeau \& Higgins, 1995; Bolt, Killough \& Koh, 2001; Shih, 2006; Sahin, 2008; Shu, Tu \& Wang, 2011). In a Turkish study, Goktas (2011) used a sample of physical education and sport students to study self-confidence in the use of ICT. Differences in self-confidence were related to having a computer at home, and preservice teachers had higher levels of self-confidence than students in other physical education departments. Additionally, it was found that outcome expectations were positively related to computer skills (Compeau \& Higgins, 1995) and technology integration performance (Perkmen \& Pamuk, 2011).

Thus, the construct of technology integration self-efficacy (TISE) has evolved, referring to an individual confidence in performing technology related tasks (Nathan, 2009). In contrast, the technology integration outcome expectations (ITOE) is defined by Niederhauser and Perkmen (2010) as the motivational force influencing a teacher to use technology during instruction, along with the anticipated outcomes of using instructional technology in the classroom (Perkmen, 2008).

\section{Purpose}

Considering the above-mentioned studies, TPACK, TISE and ITOE are critical dimensions for ensuring teacher integration of technology into education. However, characteristics of pre-service teachers have not been examined in detail, particularly for 
PE teachers. Therefore, the purpose of this study was to 1) identify the Technological Pedagogical Content Knowledge (TPACK), Technology Integration Self Efficacy (TISE) and Instructional Technology Outcome Expectations (ITOE) of pre-service physical education teachers; 2) examine the relationships among TPACK, TISE and ITOE; and 3) examine the differences between pre-service physical education teachers who did and did not perceive technology integration throughout their university education by their instructors on TPACK, TISE, and ITOE. Specifically, the following research questions were posed: 1) What are the TPACK, TISE and ITOE of pre-service physical education teachers; 2) Are there relationships among TPACK, TISE and ITOE; and 3) Do the TPACK, TISE, and ITOE of pre-service physical education teachers differ by way of the perceptions of the university instructors' integration of technology in teaching?

\section{Methods}

The research design in this study was descriptive and depended on survey data collected from a random sampling of 14 universities representing all seven geographical regions of Turkey. Prior to the study, approval from the Institutional Review Board for ethical issues was obtained.

For selecting the sample, the targeted group was the population of third and fourth year pre-service physical education teachers who were enrolled in an undergraduate program in Turkey. Physical education teacher education programs in Turkey were initially identified from the 2006 report of the Higher Education Council, Students Selection and Placement Center of Turkey (SSPC, 2006). According to the SSPC (2006) report, there were 48 universities that offered physical education teacher education programs in Turkey. Third and fourth-year students were chosen as the participants in this study because of their longer and richer experiences in the research interest of the current study topic, compared with the first and second-year students. The SSPC (2006) report indicated that the total number of students studying in the third and fourth years was approximately 4100 .

The seven geographical regions included Mediterranean, Eastern Anatolia, Aegean, Southern Eastern Anatolia, Central Anatolia, Black Sea and Marmara. The number of universities in each region ranged from three to eleven. Universities were selected randomly from each region in multiples of five. That is, one university was selected from a region including less than five universities, two universities were selected where a region contained five to ten universities, and three universities were selected from regions including more than ten universities. Consequently, a total of 14 out of 48 total universities were selected to ensure the representativeness of the whole population.

The 14 universities together had approximately 1090 pre-service PE teachers in the third and fourth yearss. All third and fourth year students from those universities were targeted as participants of the study. The surveys were posted to physical education teacher education departments after receiving permission from the chair of each department in the 2010 fall semester. An academic staff person from each faculty administered the questionnaires in a classroom setting and returned the surveys by mailing them to the researchers. In some of the universities, a researcher visited the departments and collected the surveys. Of the 1090 pre-service teachers, 760 completed the surveys (third years $=392$, fourth years $=368 ; 427$ men and 323 women). 


\section{Instruments}

Three surveys were used after an adaptation and validation study for pre-service physical education teachers. These were (1) Survey of TPACK (Schmidt, et al., 2009); (2) Survey of TISE (Perkmen, 2008); and (3) Survey of ITOE (9 items) (Niederhauser \& Perkmen, 2010) (see Appendix for sample items).

A preliminary study was completed on the adaptation and validation of the three surveys (TPACK, TISE and ITOE) before beginning the current study (Semiz \& Ince, $2011)$. The surveys were applied to 435 third $(n=249)$ and fourth year $(n=186)$ preservice PE teachers (289 males and 146 females) in 9 public universities.

\section{TPACK survey}

The original TPACK contains 58 items along a 5-point Likert-type scale (See Schmidt, et al., 2009) and has 7 subscales, including Technological Knowledge (TK), Pedagogical Knowledge (PK), Content Knowledge (CK), Technological Pedagogical Knowledge (TPK), Technological Content Knowledge (TCK), Pedagogical Content Knowledge (PCK), and Technological Pedagogical Content Knowledge (TPCK).

In addition to the seven subscales, the survey included a three-item "Models of TPACK" section, the scale for which was $25 \%$ or less, $26 \%-50 \%, 51 \%-75 \%$ and $76 \%$ $100 \%$. In the 3-item "Models of TPACK" section, items included questions, such as "In general, approximately what percentage of your teacher education professors have provided an effective model of combining content, technologies and teaching approaches in their teaching?" (see the original version in http://mkoehler.educ. msu.edu/unprotected_readings/TPACK_Survey/Schmidt_et_al_Survey_v1.pdf). For the adaptation study, the above-mentioned TPACK (Schmidt, et al., 2009; March 3, 2009 version) was translated into Turkish using a standard protocol (Vallerand, 1989). Two bilingual translators first translated the survey from English to Turkish. After the translations were compared, the differences were identified, and a final Turkish version was prepared with the consensus of the translators. Then, the Turkish version was translated back into English by another English language expert. It was observed that the back-translated items and the original English items were similar to one another. The Turkish version was then adapted to a physical education setting by a physical education expert with a PhD degree in a sports pedagogy field. During this adaptation process, the number of items was reduced from 58 to 37 (except openended questions). This reduction occurred because an item on a certain topic was asked for 4 different subject areas in the original survey, namely, mathematics, literacy, science and social studies. After modification, these questions were re-written specifically for physical education. For example, within the PCK part of the questionnaire the item "I know how to select effective teaching approaches to guide student thinking and learning" item was re-written as "I know how to select effective teaching approaches to guide student thinking and learning in physical education and sports".

In addition, two open-ended questions were added, including 1) "Describe a specific episode where a professor or instructor in your university effectively demonstrated or modelled the task of combining content, technology and teaching approaches in a classroom lesson. Please include in your description what content was being taught, what technology was used, and what teaching approaches were implemented"; and 2) "Describe a specific episode where you effectively demonstrated or modelled combining content, technologies and teaching approaches in a classroom lesson. Please 
include in your description what content was being taught, what technology was used, and what teaching approaches were implemented. If you have not observed a teacher modelling, please indicate so."

Before administering the survey in the pilot study, face validity was checked by administering the survey to 20 students to understand whether the modified survey was clear and easy to understand. Feedback from the participants indicated that the surveys were appropriate. Surveys were then applied to participants for use in the adaptation and validation study. Confirmatory factor analysis (CFA) was conducted, and Cronbach alpha coefficients were calculated.

Data revealed five factors in the Turkish TPACK for pre-service physical education teachers instead of seven factors in the original English form. According to the findings, the PK subscale items in the Turkish version combined with PCK subscale and formed a PK+PCK subscale. TPK subscale items were combined with the TCK subscale to form a TPK+TCK subscale. By the end, the Turkish TPACK survey for the pre-service physical education teachers included 5 subscales: TK, CK, PK+PCK, TPK+TCK and TPCK subscales, two "Models of TPACK" sections, and two more open-ended question. The CFA administered with AMOS 18 showed acceptable fit indices for TPACK as $\chi^{2}=889 ; \mathrm{df}=395 ; \chi^{2} / \mathrm{df}=2.25 ; \mathrm{CFI}=0.92 ; \mathrm{TLI}=0.92$ and RMSA $=0.054$. Cronbach's alpha for each subscale ranged from .77 to .95 (Semiz \& Ince, 2011).

\section{TISE survey}

The TISE survey, originally available in Turkish, was constructed for the pre-service teachers in general (Perkmen, 2008). TISE includes 16 items with a 5-point Likert format and contains no subscales. Each item begins with "I feel confident ...", and asks for teachers' perceptions of the integration of technology into teaching. Adaptation and validation study data CFI (.94) and TLI (.95) scores indicated a good fit (Maruyama, 1998; Schumacher \& Lomax, 1996). Similarly, chi-squared - degrees of freedom ratio resulted in a good fit, $\chi^{2}=324 ; \mathrm{df}=98 ; \chi^{2} / \mathrm{df}=3.3$ (Wheaton, et al., 1977). Internal consistency of the scale was high (Cronbach alpha $=0.95)$ (Nunnally, 1978). Based on the CFA and internal consistency findings, the TISE survey for pre-service physical education teachers was accepted as a valid survey for assessing the related characteristics of this population (Semiz \& Ince, 2011).

\section{ITOE survey}

The ITOE survey, available in Turkish, was originally constructed for the pre-service teachers in general (Niederhauser \& Perkmen, 2010). ITOE includes 9 items with a 5point Likert format and contains no subscales. The items include phrases to facilitate the prediction of participants' expectations using technology in their teachings, such as "Integrating technology into my future classroom activities will likely allow me to...".

CFA applied to the adaptation and validation data resulted in unsatisfactory fit indices, $\chi^{2}=442.5 ; \mathrm{df}=27 ; \chi^{2} / \mathrm{df}=16.3 ; \mathrm{CFI}=0.82 ; \mathrm{TLI}=0.77$ and RMSA $=0.189$. Post hoc model modifications were performed in an attempt to develop a better model fit. Because item 9 had high standardised residual covariances with items 1, 2, 3, 4, 5, 7, 8, it was excluded from the model and the model was re-estimated, $\chi^{2}=47.2 ; \mathrm{df}=14$; $\chi^{2} / \mathrm{df}=3.3 ; \mathrm{CFI}=0.98 ; \mathrm{TLI}=0.97$ and RMSA $=0.074$. This revised model indicated better fitting after item 9 was removed. Internal consistency of the 8-item scale was high (Cronbach alpha $=0.91$ ) (Nunnally, 1978). Based on the CFA and internal consistency findings, the modified 8-item ITOE survey for pre-service physical 
education teachers was accepted as a valid survey to assess the related characteristics of this population (Semiz \& Ince, 2011).

\section{Data analysis}

Prior to analyses, the data were screened to correct any entry errors and evaluate any missing data. Among the 760 participants, four had missing values more than $5 \%$ of the time and were thus deleted. The remaining missing data were replaced with the mean of the specific variable. The skewness and kurtosis was used to examine the normality of the distribution, and no values higher than +3 or less than -3 were found to suggest that an outlier be excluded (Tabachnick \& Fidell, 2007). Therefore, analyses were carried out with 756 subjects.

Next, TPACK, TISE and ITOE survey data for the first research question were analysed with descriptive statistics. Answers to open-ended questions in the TPACK survey were first coded and descriptive statistics produced. The second research question was analysed through the use of canonical correlation to identify relationships among TPACK, TISE and ITOE. The canonical correlation method is accepted as most appropriate when the relationship between two data sets is examined (Sherry and Henson, 2005; Tabachnick \& Fidell, 2007). In this study, TPACK is a data set with 5 sub-dimensions, and TISE and ITOE are considered together as a second data set named as "Sense of self" rooted on Bandura's social cognitive theory (Bandura, 1986).

For the third research question, the participants were first categorised into one of two groups: pre-service physical education teachers (1) who perceived, or (2) who did not experience technology integration throughout their university education by their instructors.

In making this categorisation, the participants' answers to the three-item "Models of TPACK" section were used. If the mean of these three questions was less than 3 for a given participant, s/he was categorised as "did not perceive technology integration throughout their university education by their instructors". A participant whose mean was greater than 3 was considered as having "perceived technology integration throughout their university education by their instructors". After categorisation, multivariate analysis of variance (MANOVA) was used to analyse the TPACK data for all subscales. TISE and ITOE data were analysed by independent $t$-tests for the third research question.

\section{Findings}

\section{First research question}

According to the TPACK data, pre-service physical education teachers perceived their technological pedagogical content knowledge to generally be at a good level $(M=3.90$, $S D=.46$ ) in a range of 1 to 5 (See Table 1). Similarly, the perceptions of self-efficacy ( $M$ $=3.96, S D=.56)$ and awareness of the benefits of instructional technologies $(M=4.09$, $S D=.68$ ) were deemed to be at good levels.

Among the 756 participants in this study, $343(45 \%)$ completed the open-ended questions. The questions examined university instructors' insufficient use of technology in education. The participants identified the lack of 1) technology that their schools offer $(f=36) ; 2)$ use of computers and projection devices $(f=196) ; 3)$ overhead 
projectors $(f=66) ; 4)$ videos $(f=23)$; and 5) smart boards (interactive whiteboards) $(f=$ 11). In addition, pre-service physical education teachers primarily reported the use of a direct instructional approach or teacher-centred approaches in their university courses by their instructors $(f=130)$.

\section{Table 1: Mean TPACK scores}

\begin{tabular}{|l|l|c|c|}
\hline Survey & \multicolumn{1}{|c|}{ Subscales } & $M$ & $S D$ \\
\hline \multirow{5}{*}{ TPACK } & Whole scale & 3.90 & .46 \\
\cline { 2 - 4 } & TK & 3.71 & .68 \\
\cline { 2 - 4 } & CK & 3.92 & .63 \\
\cline { 2 - 4 } & PK+PCK & 4.05 & .49 \\
\cline { 2 - 4 } & TPK+TCK & 3.84 & .55 \\
\cline { 2 - 4 } & TPCK & 3.96 & .59 \\
\hline \multicolumn{1}{|l}{ TISE } & 3.96 & .56 \\
\hline \multicolumn{2}{|l}{ ITOE } & 4.09 & .68 \\
\hline
\end{tabular}

Pre-service physical education teachers reported that they used computers and projection devices $(f=139)$, overhead projectors $(f=16)$ and videos $(f=10)$ when they present or teach. In addition, the teachers also reported employing direct instruction $(f$ $=45)$ and demonstration $(f=20)$ methods in their teaching experiences, similar to their university professors.

\section{Second research question}

Canonical correlation analyses suggest that technological pedagogical content knowledge variables have significant and positive relationships with technology integration self-efficacy and instructional technology outcome expectations $(\mathrm{Rc}=.77)$ (Tabachnick \& Fidell, 2007). Additionally, the results show that technology integration self-efficacy has a considerably stronger relationship with technological pedagogical content knowledge than with instructional technology outcome expectations. These relationships were moderate and positive (see Figure 1).

\section{Third research question}

According to the findings, pre-service physical education teachers who perceived technology integration into their instruction, perceived higher technological pedagogical content knowledge, higher technology integration self-efficacy and higher instructional technology outcome expectations compared with the pre-service teachers who did not perceive technology integration by their university instructors, $\lambda=0.87$, $F(5,750)=22.27, p<.05$ (Table 2 )

Table 2: Group means and standard deviations for TPACK and its subscales

\begin{tabular}{|c|c|c|c|c|}
\hline \multirow{3}{*}{ Scale } & \multicolumn{4}{|c|}{ Perception of technology integration } \\
\hline & \multicolumn{2}{|c|}{$\begin{array}{l}\text { Did not perceive technology integration } \\
\text { by the university instructors }(n=542)\end{array}$} & \multicolumn{2}{|c|}{$\begin{array}{l}\text { Perceived technology integration by the } \\
\text { university instructors }(n=214)\end{array}$} \\
\hline & $M$ & $S D$ & $M$ & $S D$ \\
\hline TK & 3.48 & .74 & 3.80 & .64 \\
\hline CK & 3.67 & .71 & 4.02 & .57 \\
\hline $\mathrm{PK}+\mathrm{PCK}$ & 3.90 & .59 & 4.11 & .44 \\
\hline TCK+TPK & 3.54 & .64 & 3.96 & .47 \\
\hline TPCK & 3.70 & .72 & 4.06 & .50 \\
\hline TPACK & 3.67 & .54 & 3.99 & .38 \\
\hline
\end{tabular}




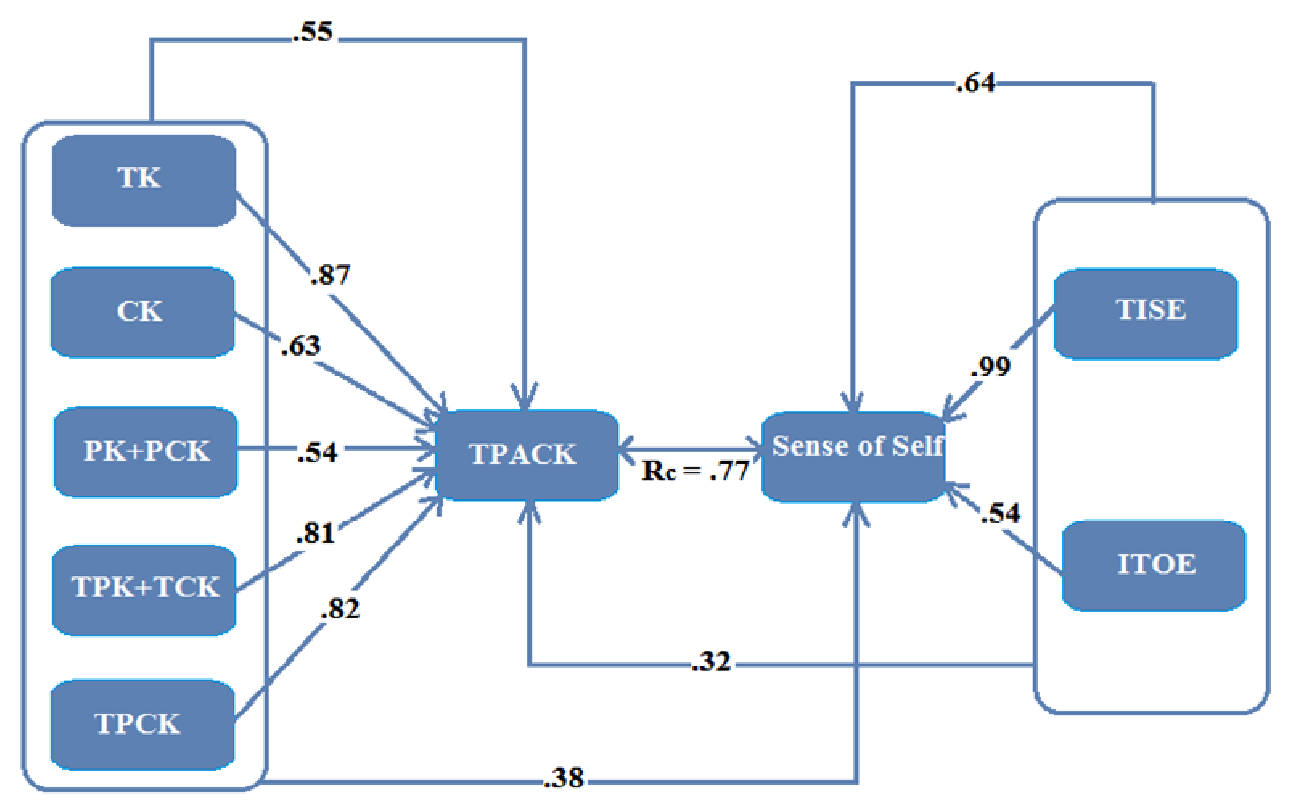

Figure 1: General view of canonical correlation analysis

According to the independent t-test results, TISE and ITOE variables were significantly higher in the pre-service physical education teachers group who perceived technology integration $(p<.05$.) (Table 3).

Table 3: Group differences for technology integration self-efficacy and instructional technology outcome expectations

\begin{tabular}{|c|c|c|c|c|c|c|}
\hline Survey & Group & $N$ & $M$ & $S D$ & $d f$ & $t$ \\
\hline \multirow[t]{2}{*}{ TISE } & $\begin{array}{l}\text { Perceived technology } \\
\text { integration }\end{array}$ & 542 & 4.06 & .49 & \multirow[t]{2}{*}{754} & \multirow[t]{2}{*}{7.78} \\
\hline & $\begin{array}{l}\text { Did not perceive } \\
\text { technology integration }\end{array}$ & 214 & 3.72 & .68 & & \\
\hline \multirow[t]{2}{*}{ ITOE } & $\begin{array}{l}\text { Perceived technology } \\
\text { integration }\end{array}$ & 542 & 4.16 & .59 & \multirow[t]{2}{*}{754} & \multirow[t]{2}{*}{4.35} \\
\hline & $\begin{array}{l}\text { Did not perceive } \\
\text { technology integration }\end{array}$ & 214 & 3.92 & .85 & & \\
\hline
\end{tabular}

\section{Discussion}

Findings on technological pedagogical content knowledge, technology integration selfefficacy and instructional technology outcome expectations indicate that pre-service physical education teachers' technology-related perceptions are not lower than those of other subject matter pre-service teachers in other countries (Koh, Chai \& Tsai, 2010; Niederhauser \& Perkmen, 2010). Even the perception of technological pedagogical content knowledge amongst the current study participants was slightly higher than the findings reported in Koh, Chai and Tsai (2010) for Singaporean pre-service teachers. 
An interesting finding is the perception of university instructors' poor modelling of technology integration by pre-service teachers. This finding suggests that university instructors could be better role models for technology integration. In addition, preservice teachers reported that the use of technology consisted mainly of PowerPoint presentations, computers and projectors. The use of physical education and sportspecific technologies, such as sport-specific videos, were reportedly quite low, and no use of pedometers, heart rate monitors, specific software for analysing movement, or other emerging technologies, such as exergames, was reported. Emerging physical education and sport-specific technologies may not be sufficiently present in the education of pre-service physical education teachers. Physical education teacher education programs should therefore consider the integration of physical education and sports-specific technologies in addition to other general instructional technology tools in their curricula.

The current study indicated significant and positive relationships between technological pedagogical content knowledge variables, and technology integration self-efficacy and instructional technology outcome expectations. Considerably stronger relationships amongst technology integration self-efficacy and technological pedagogical content knowledge than with instructional technology outcome expectations were found. Similarly, Nathan (2009) found moderate relationships between technological pedagogical content knowledge and technology integration selfefficacy of pre-service teachers in four different subject areas (math, science, literacy and social studies). In another study conducted with pre-service teachers (including mostly elementary education and early childhood education), Perkmen and Pamuk (2011) found a significant relationship between technology integration self-efficacy and instructional technology outcome expectations. More specifically, the current study indicates that having a high self-efficacy for integrating technology likely means having high technology integration outcome expectations and high technological pedagogical content knowledge in pre-service physical education teachers, similar to the findings in studies of other subject matter teachers.

In the third research question, pre-service physical education teachers who perceived technology integration by their university professors have higher TPACK, TISE and ITOE than those who did not perceive such technology integration. A study by Ince and Ok (2005) indicated that when pre-service teachers have a chance to observe contemporary approaches in teaching from their own university instructors, they internalise these approaches and accept their instructors as role models. Findings from the current study support their finding in terms of the positive effect of perceived technology integration on pre-service teachers' technological pedagogical content knowledge, technology integration self-efficacy and instructional technology outcome expectations. In addition, the results from previous studies that identified a positive influence of intervention programs on improving the technological pedagogical content knowledge perception of in-service and pre-service teachers (Angeli \& Valanides, 2009; Mishra \& Koehler, 2006) also imply that if quality intervention programs are prepared for the integration of technology in physical education teaching, then pre-service physical education teachers can improve their use of technology in their teaching.

This study extended the knowledge on the use of technology in education by identifying the perception of pre-service physical education teachers' technological pedagogical content knowledge, technology integration self-efficacy and instructional technology outcome expectations, by providing evidence within the Turkish context. 
Moreover, the findings from this study also suggest that the significant and positive relationship of technological pedagogical content knowledge variables with technology integration self-efficacy and instructional technology outcome expectations, in our sample of pre-service physical education teachers, mirrors those reported in samples of other subject matter teachers reported in the literature. Finally, our findings indicate that if university instructors can be good role models with technology integration, then pre-service physical education teachers will benefit by improving their own TPACK, TISE and ITOE perceptions.

However, several limitations and strengths should be taken into consideration in evaluating our findings. First, participants of the current study were selected from third and fourth years of their physical education teacher education departments. Therefore, when generalising the findings to the population, it should be taken into consideration that the first and second years were not included. Second, perceptions of pre-service teachers of their university instructors' role modelling in the use of technology may have been influenced by their poor understanding of TPACK. Third, data collection methods depended on the survey approach. Limitations inherent to survey research are also applicable for this study. Data collection methods, such as clustered and random sampling as well as the attainment of a high percentage of the population, support the generalisability of our results.

\section{Conclusion and recommendations}

In conclusion, the current study suggests that technological pedagogical content knowledge, technology integration self-efficacy, and instructional technology outcome expectation perceptions of pre-service physical education teachers are at satisfactory levels. However, university instructors are not good role models for the use of technology integration for the pre-service physical education teachers. According to the pre-service teachers' reports, integration of physical education and sports-related emerging technologies is nearly non-existent in the teaching practices in the university setting. Technological pedagogical content knowledge, technology integration selfefficacy and instructional technology outcome expectation variables are moderately related among each other according to the pre-service physical education teacher perceptions in Turkey. Moreover, pre-service teachers' perceptions of their university instructors' integration of technology into their teaching in university positively influence their own perceptions of technological pedagogical content knowledge, technology integration self-efficacy and instructional technology outcome expectations.

Technology intervention can develop teachers' TPACK level in language arts and social sciences (Tee \& Lee, 2011). Therefore, professional development programs for teacher education program instructors in technology integration in teaching and in emerging physical education and sports-related technologies should be provided. Teacher education departments should be supported with up-to-date educational technologies, and the reason for the infrequent use of emerging physical education and sports-related technologies in teacher education programs should be examined.

\section{References}

Agyei, D. D. \& Voogt, J. (2012). Developing technological pedagogical content knowledge in pre-service mathematics teachers through collaborative design. Australasian Journal of Educational Technology, 28(4), 547-564. http: / / www.ascilite.org.au/ ajet/ ajet28/agyei.html 
Angeli, C. \& Valanides, N. (2009). Epistemological and methodological issues for the conceptualization, development, and assessment of ICT-TPCK: Advances in technological pedagogical content knowledge (TPCK). Computers $\mathcal{E}$ Education, 52(1), 154-168. http: / / dx.doi.org/10.1016/j.compedu.2008.07.006

Bandura, A. (1986). Social foundations of thought and action: A social cognitive theory. Englewood Cliffs, NJ: Prentice-Hall.

Bandura, A. (1997). Self-efficacy: The exercise of control. New York, NY: Freeman.

Bolt, M. A., Killough, L. N. \& Koh, H. C. (2001). Testing the interaction effects of task complexity in computer training using the social cognitive model. Decision Sciences, 32(1), 1-20. http: / / dx.doi.org/10.1111/j.1540-5915.2001.tb00951.x

Compeau, D. R. \& Higgins, C. A. (1995), Application of social cognitive theory to training for computer skills. Information Systems Research, 6(2),118-143. http: / / dx.doi.org/10.1287/ isre.6.2.118

Cote, P., Chen, S. \& Keppell, M. J. (2008). New perspectives in physical education: Using online learning to promote critical thinking and collaborative skills. Asian Journal of Exercise E Sports Science, 5(1), 57-61. http:/ / js.sagamorepub.com/ajess/article/view/ 2479

Cox, S. (2008). A conceptual analysis of technological pedagogical content knowledge. Unpublished Doctoral Dissertation, Brigham Young University. http:/ / hdl.lib.byu.edu/1877/etd2552

Gao, P., Tan, S. C., Wang, L., Wong, A. \& Choy, D. (2011). Self reflection and preservice teachers' technological pedagogical knowledge: Promoting earlier adoption of student-centred pedagogies. Australasian Journal of Educational Technology, 27(6), 997-1013. http:/ / www.ascilite.org.au/ajet/ajet27/gao.html

Goktas, Z. (2011). The self-confidence levels of physical education and sport students towards information and communication technologies (ICT). Nigde University Journal of Physical Education and Sport Sciences, 5(1), 50-57. [in Turkish]

http: / / dergi.nigde.edu.tr/index.php/ besyodergi/article/view/247 / 165

Ince, M. L., Goodway, J. L., Ward, P. \& Lee, M. A. (2006). The effects of professional development on technological competency and the attitudes urban physical education teachers have toward using technology. Journal of Teaching in Physical Education, 25(4), 428440. http:/ / journals.humankinetics.com/jtpe-back-issues/jtpevolume25issue4october/ chapter6theeffectsofprofessionaldevelopmentontechnologicalcompetencyandtheattitudes urbanphysicaleducationteachershavetowardusingtechnology

Ince, M. L. \& Ok, A. (2005). Moving prospective physical education teachers to learner centered teaching: Can it be stimulated in a traditional context? Journal of International Council for Health, Physical Education, Sport and Dance, 41(1), 6-12.

Jones, A. \& Moreland, J. (2004). Enhancing practicing primary school teachers' pedagogical content knowledge in technology. International Journal of Technology and Design Education, 14(2), 121-140. http: / / dx.doi.org/10.1023/B\%3AITDE.0000026513.48316.39

Koh, J. H. L., Chai, C. S. \& Tsai, C. C. (2010). Examining the technological pedagogical content knowledge of Singapore pre-service teachers with a large-scale survey. Journal of Computer Assisted Learning, 26(6), 563-573. http: / / dx.doi.org/10.1111/j.1365-2729.2010.00372.x

Kretschmann, R. (2010). Physical education 2.0. In Ebner, M. \& Schiefner, M. (Eds.), Looking toward the future of technology-enhanced education: Ubiquitous learning and the digital native, pp. 432-454. Hershey, USA: IGI Global.

Lee, M. H., \& Tsai, C. C. (2008). Exploring teachers' perceived self efficacy and technological pedagogical content knowledge with respect to educational use of the world wide web. Instructional Science, 38(1), 1-21. http: / / dx.doi.org/10.1007/s11251-008-9075-4 
Lent, R. W., Brown, S. D. \& Hackett, G. (2002). Social cognitive career theory. In D. Brown (Ed.), Career choice and development (pp. 255-311). San Francisco, CA: Jossey-Bass.

MacDonald, D. \& Hay, P. (2010). Health \& physical education as/and technology: An Australian perspective. Presented at Global Forum for Physical Education Pedagogy 2010, Iowa, USA. [PowerPoint, 2.9 MB] http: / / www.globalpeforumgc.org/sites/default/files/presentations/Macdonald-Hay.pdf

Maruyama, G. M. (1998). Basics of structural equation modeling. Thousand Oaks: Sage.

Mavi, H. F. (2007). The informatics technology usage of undergraduate students in physical education and sport department. Presented at 7th International Educational Technology Conference, Near East University, Northern Cyprus.

McCaughtry, N., Oliver, K. L., Dillon, S. R. \& Martin, J. J. (2008). Teachers' perspectives on the use of pedometers as instructional technology in physical education: A cautionary tale. Journal of Teaching In Physical Education, 27(1), 83-89. http:/ / journals.humankinetics.com/ jtpe-back-issues/jtpevolume27issue1january/teachersperspectivesontheuseofpedometers asinstructionaltechnologyinphysicaleducationacautionarytale

Mishra, P. \& Koehler, M. J. (2006). Technological pedagogical content knowledge: A framework for teacher knowledge. Teachers College Record, 108(6), 1017-1054. http: / / www.tcrecord.org/ Content.asp?ContentID=12516

Mohamed, H. A. M. \& El Rheem, R. N. A. (2010). The web quest: Its impact on developing teaching skills of physical education student teachers. ICHPER SD Journal of Research, 5(1), 10-15. http: / / www.eric.ed.gov/ PDFS / EJ903497.pdf

Mohnsen, B. (2008). Using technology in physical education (6th ed.). Cerritos, CA: Bonnie's Fitware Inc.

NASPE (National Association for Sport and Physical Education) (2009). Appropriate use of instructional technology in physical education. Position Statement. Reston, VA: NASPE. http: / / www.aahperd.org/naspe/ standards/ upload / Appropriate-Use-of-InstructionalTechnology-in-PE-2009-2.pdf

Nathan, E. J. (2009). An examination of the relationship between pre-service teachers' level of technology integration self efficacy (TISE) and technological pedagogical content knowledge (TPACK). Unpublished Doctoral Dissertation, University of Houston.

Niederhauser, D. S. \& Perkmen, S. (2010). Beyond self-efficacy: Measuring preservice teachers' instructional technology outcome expectations. Computers in Human Behavior, 26(3), 436-442.

Nunnally, J. C. (1978). Psychometric theory (2nd ed.). New York: McGraw-Hill.

Perkmen, S. (2008). Factors that influence pre-service teachers' technology integration performance. Doctoral Dissertation, Iowa State University, 2008. Dissertation Abstracts International, 69(06), 109.

Perkmen, S. \& Pamuk, S. (2011). Social cognitive predictors of pre-service teachers' technology integration performance. Asia Pacific Educational Review, 12(1), 45-58. http: / / dx.doi.org/ 10.1007/ s12564-010-9109-x

Roblyer, M. D. \& Doering, A. H. (2005). Integrating educational technology into teaching. Lebanon: Pearson.

Russell, W. (2007). Physical educators' perceptions and attitudes toward interactive video game technology within the physical education curriculum. Missouri Journal of Health, Physical Education, Recreation and Dance, 17, 76-89. 
Sahin, I. (2008). From the social-cognitive career theory perspective: A college of education faculty model for explaining their intention to use educational technology. Journal of Educational Computing Research, 38(1), 51-66. http: / / dx.doi.org/ 10.2190/EC.38.1.c

Schmidt, D. A., Baran, E., Thompson, A. D., Mishra, P., Koehler, M. J. \& Shin, T. (2009). Technological pedagogical content knowledge (TPACK): The development and validation of an assessment instrument for preservice teachers. Journal of Research on Technology in Education, 42(2), 123-149. http:/ / www.eric.ed.gov/ERICWebPortal/ contentdelivery / servlet/ERICServlet?accno=EJ868626

Schumacher, R. E. \& Lomax, R. G. (1996). A beginner's guide to structural equation modelling. New Jersey: Erlbaum.

Semiz, K. \& Ince, M. L. (2011). Adaptation and validation of teachers' knowledge of teaching and technology, technology integration self-efficacy and outcome expectations questionnaires for preservice PE teachers. 16th Annual ECSS Congress Book of Abstracts, 49, Liverpool, England.

Sherry, A. \& Henson, R. K. (2005). Conducting and interpreting canonical correlation analysis in personality research: A user-friendly primer. Journal of Personality Assessment, 84(1), 37-48. http: / / dx.doi.org/10.1207/s15327752jpa8401_09

Shih, H. P. (2006). Assessing the effects of self-efficacy and competence on individual satisfaction with computer use: An IT student perspective. Computers in Human Behavior, 22(6), 1012-1026. http: / / dx.doi.org/10.1016/j.chb.2004.03.025

Shu, Q., Tu, Q. \& Wang, K. (2011). The impact of computer self-efficacy and technology dependence on computer-related technostress: A social cognitive theory perspective. International Journal of Human-Computer Interaction, 27(10), 923-939. http: / / dx.doi.org/ 10.1080/10447318.2011.555313

Shulman, L. S. (1987). Knowledge and teaching: Foundations of the new reform. Harvard Educational Review, 57(1), 1-22. http:/ / www.hepg.org/her/abstract/ 461

So, H.-J, \& Kim, B. (2009). Learning about problem based learning: Student teachers integrating technology, pedagogy and content knowledge. Australasian Journal of Educational Technology, 25(1), 101-116. http:/ / www.ascilite.org.au/ajet/ajet25/ so.html

Strand, B. \& Bender, V. (2011). Knowledge and use of appropriate instructional strategies by physical education teachers. Physical Educator, 68(1). http: / / js.sagamorepub.com/ pe/article/view / 25

Students Selection and Placement Center of Turkey (2006). Yuksekogretim programlari ve kontenjanlari kilavuzu. [viewed 16 Jan 2011] http:/ / www.osym.gov.tr

Tabachnick, B. G., \& Fidell, L. S. (2007). Using multivariate statistics (5th ed.). New York: Allyn and Bacon.

Tee, M. Y. \& Lee, S. S. (2011). From socialisation to internalisation: Cultivating technological pedagogical content knowledge through problem-based learning. Australasian Journal of Educational Technology, 27(1), 89-104. http: / / www.ascilite.org.au/ajet/ ajet27/ tee.html

Turkish Physical Education Curriculum (2007). Beden Egitimi Dersi (1.-8. Siniflar) Ogretim programi ve kilavuzu. Ankara: Devlet Kitaplari Müdürlügü.

Vallerand, R. J. (1989). Toward a methodology for the transcultural validation of psychological questionnaires: Implications for research in the French language. Canadian Psychology/Psychologie Canadienne, 30(4), 662-680. http: / / psycnet.apa.org/journals/ cap/30/4/ 
Wheaton, B., Muthen, B., Alwin, D. F. \& Summers, G. F. (1977). Assessing reliability and stability in panel models. Sociological Methodology, 8(1), 84-136. http: / / www.jstor.org/ stable/ 270754

Wojcicki, T. R., White, S. M. \& McAuley, E. (2009). Assessing outcome expectations in older adults: The multidimensional outcome expectations for exercise scale. The Journals of Gerontology Series B: Psychological Sciences and Social Sciences, 64B(1), 33-40. http: / / dx.doi.org/10.1093/geronb/gbn032

Woods, M. L., Karp, G. G., Hui, M. \& Perlman, D. (2008). Physical educators' technology competencies and usage. Physical Educator, 65(2), 82-99. http:/ / ro.uow.edu.au/edupapers/319/

Yaman, C. (2008). The abilities of physical education teachers in educational technologies and multimedia. Turkish Online Journal of Educational Technology, 7(2), 20-31. http: / / www.tojet.net/articles/v7i2/723.pdf

Yaman, M. (2007). The competence of physical education teachers in computer use. Turkish Online Journal of Educational Technology, 6(4), 46-55. http: / / www.tojet.net/ articles / v6i4/645.pdf

Yilmaz, I. (2008). Beden egitimi ve spor ogretim elemanlarinin teknolojiye iliskin tutumlarinin degerlendirilmesi. Turkiye Sosyal Arastirmalar Dergisi, 12(1), 135-147.

Yilmaz, I., Ulucan, H. \& Pehlivan, S. (2010). Beden egitimi ogretmenligi programinda ogrenim goren ogrencilerin egitimde teknoloji kullanimina iliskin tutum ve dusunceleri. Ahi Evran Universitesi Egitim Fakultesi Dergisi, 11(1), 105-118.

\section{Appendix: Survey items}

Sample items from the surveys (5-point Likert scales).

\section{Technological Pedagogical and Content Knowledge (TPACK) survey}

Technology Knowledge (TK)

I know how to solve my own technical problems.

I can learn technology easily.

I had sufficient opportunities to work with different technologies.

Content Knowledge (CK)

I have sufficient knowledge about movement skills.

I have sufficient knowledge about healthy and active living skills.

I have various ways and strategies of developing my understanding of physical education and sports.

Pedagogical Knowledge (PK) and Pedagogical Content Knowledge (PCK)

I can adapt my teaching based-upon what students currently understand or do not understand.

I can adapt my teaching style to different learners.

I know how to select effective teaching approaches to guide student thinking and learning in physical education and sports.

Technological Content Knowledge (TCK) and Technological Pedagogical Knowledge (TPK)

I know about technologies that I can use for understanding and doing physical education and sports.

I can choose technologies that enhance students' learning for a lesson. 
My teacher education program has caused me to think more deeply about how technology could influence the teaching approaches I use in my classroom.

Technology Pedagogy and Content Knowledge (TPCK)

I can teach lessons that appropriately combine physical education and sports, technologies and teaching approaches.

I can select technologies to use in my classrooms that enhance what I teach, how I teach and what students learn.

I can choose technologies that enhance the content for a lesson.

\section{Technology Integration Self Efficacy (TISE) Survey}

I feel confident that I can teach relevant subject matter with appropriate use of instructional technology.

I feel confident that I can select appropriate instructional technology for instruction based on curriculum standards-based pedagogy.

I feel confident that I can regularly incorporate appropriate instructional technologies into my lessons to enhance student learning.

I feel confident that I can help students when they have difficulty with instructional technology.

\section{Instructional Technology Outcome Expectations (ITOE) Survey}

Using instructional technology in the classroom will increase my effectiveness as a teacher.

Using instructional technology in the classroom will increase my productivity.

Using instructional technology in the classroom will make my teaching more exiting.

Using instructional technology in the classroom will make my teaching more satisfying.

Authors: Kivanc Semiz, PhD student, is with the Faculty of Education, Physical Education and Sports Department, Middle East Technical University, Ankara, Turkey. His research interests include technology integrated physical education and sports pedagogy. Email: ksemiz@metu.edu.tr

Dr Mustafa Levent Ince, Associate Professor, is with the Faculty of Education, Physical Education and Sports Department, Middle East Technical University, Ankara, Turkey. His research interests include instructional designs in physical education and sports, and professional development of teachers and sports coaches.

Email: mince@metu.edu.tr

Please cite as: Semiz, K. \& Ince, M. L. (2012). Pre-service physical education teachers' technological pedagogical content knowledge, technology integration self-efficacy and instructional technology outcome expectations. Australasian Journal of Educational Technology, 28(6), 1248-1265. http: / / www.ascilite.org.au/ajet/ajet28/ semiz.html 